\title{
Inactivation of Bacterial Spores by Hydrostatic Pressure
}

\author{
By A. J. H. SALE, G. W. GOULD AND W. A. HAMILTON* \\ Unilever Research Colworth/Welwyn Laboratory, Colworth House, \\ Sharnbrook, Bedford
}

(Accepted for publication 12 November 1969)

SUMMAR Y

Spores of various species of the genera Bacillus and Clostridium were inactivated by hydrostatic pressures up to 8000 atmospheres. Inactivation was a function of holding time at pressure rather than of the compression and decompression stages. Inactivation generally proceeded more rapidly at high than at low temperatures; below about $50^{\circ}$ there was a well defined optimum pressure for inactivation, but above about $50^{\circ}$ an increase in pressure up to 8000 atmospheres caused progressively more inactivation.

Inactivation was decreased at extremes of $\mathrm{pH}$ value and by high ionic strength solutions. A proportion of the spores pressurized under certain conditions became heat-sensitive. These observations, and the chemical, phase-contrast, and electron-microscopic changes seen in pressurized spores, suggested that pressure caused inactivation of spores by first initiating germination and then inactivating the germinated forms.

\section{INTRODUCTION}

Hydrostatic pressure above 1000 atmospheres (atm.) causes a rapid inactivation of many vegetative bacteria (Hite, I899; Hite, Giddings \& Weakley, I9I4; Heden, I964) whereas spores are more resistant and may survive pressures above I2,000 atm. (Larson, Hartzell \& Diehl, I9I8; Basset \& Macheboeuf, I932). Recently we noticed, however, that under certain conditions inactivation of spores occurred more rapidly at lower hydrostatic pressures than at higher pressures. This observation was surprising, and was difficult to reconcile with the expected effect of a physical treatment on a biological system: an increase in the intensity of the treatment ought to result in an increase in the degree of inactivation of the bacteria (cf. heat, ultraviolet and ionizing radiation, electric shock, ballistic disintegration; see Roberts \& Hitchins, 1969). This anomalous effect of pressure led us to study and define the effects of environmental variables on pressure inactivation of spores more closely, with a view to explaining, first, how spores are inactivated by pressure and, secondly, why lower pressures can cause greater inactivation than higher pressures.

\section{METHODS}

Organisms. Bacteria used were Bacillus coagulans NCTC 399I and B. cereus NCTC 8035 (National Collection of Type Cultures, Colindale), $B$. cereus strains $\mathrm{T}$ and $\mathrm{PX}, B$. polymyxa м I, B. subtilis var. niger (syn. globigii), B. subtilis A (rough strain; Edwards, Busta \& Speck, 1965) and Clostridium sporogenes PA 3679.

Production of spores. Spores of the aerobes were grown on potato yeast-extract

* Present address: Department of Biological Chemistry, Marischal College, Aberdeen. 
glucose agar (Gould \& Ordal, 1968) at $30^{\circ}$ (Bacillus cereus strains) or $37^{\circ}$ (B. coagulans, B. polymyxa and B. globigii) or on the Fortified Nutrient Agar of Edwards et al. (1965) at $45^{\circ}$ (B. subtilis A). Spores of Clostridium sporogenes were grown at $37^{\circ}$ in the liquid Reinforced Clostridial Medium (Oxoid) of Gibbs \& Hirsch (1956). When sporulation and lysis of sporangia were complete the spores were washed six times with cold distilled water (using a centrifuge) and stored at $4^{\circ}$ in water at a concentration of approximately $20 \mathrm{mg}$. dry wt spores $/ \mathrm{ml}$. Suspensions of 'superdormant' spores of $B$. cereus PX and B. polymyxa (Gould, Jones \& Wrighton, I968) were prepared as follows: Spores were activated by heating at $70^{\circ}$ for $30 \mathrm{~min}$., then incubated at a concentration of about $10^{8}$ spores $/ \mathrm{ml}$. for $\mathrm{I} \mathrm{hr}$ in yeast glucose broth at $37^{\circ}$. The suspension was then heated at $70^{\circ}$ for $30 \mathrm{~min}$. to inactivate germinated spores whilst leaving viable the superdormant forms. The spores were finally recovered, washed and stored as above. Mixed spores from soil were prepared by extracting $10 \mathrm{~kg}$. portions of soil with I l. portions of cold distilled water, filtering through glass wool to remove coarse debris and concentrating the spores by repeated differential centrifugation. The final suspension was heated at $70^{\circ}$ for $30 \mathrm{~min}$. to inactivate non-spore forms and stored in water, as above.

Application of pressure. Suspensions $(2 \mathrm{ml}$.) were enclosed in sachets made from $\mathrm{I}$ in. broad polythene Layflat Tubing (Transatlantic Plastics Ltd., 45 Victoria Road, Surbiton, Surrey), using an impulse heat sealer (A. H. Bland Ltd., Winchelsea Road, Harlesden, London N.W.Io). The final seal was made through the suspension in order to exclude air bubbles. The sachets were immersed in a container of water or oil, to which the pressure was transmitted by hydraulic oil.

The high pressure intensifiers were designed following conventional techniques (Manning, 1963), and pressures up to $8000 \mathrm{~atm}$. could be reached. Pressure was measured by a manganin gauge, and temperature close to the sachets by a mineralinsulated metal-sheathed thermocouple. Temperature was controlled by circulating heated glycol from a thermostated bath through a jacket on the outside of the pressure cylinder. Pressure was normally raised in less than half a minute and lowered in less than $5 \mathrm{sec}$, unless otherwise stated. Adiabatic heating of the samples amounted to approximately $3^{\circ}$ per $1000 \mathrm{~atm}$; the temperature transient decayed in $10 \mathrm{~min}$.

Radiation. Suspensions (I ml.) were sealed into glass ampoules and subjected at ambient temperature to $\gamma$-radiation from a Co 60 source at a dose rate of about $0.6 \mathrm{mrad} . / \mathrm{hr}$.

Estimation of viability. Spores surviving the various treatments were enumerated by poured plate viable counts using nutrient agar, and incubation temperatures as listed above. Heat-sensitive forms were inactivated by heating samples at $70^{\circ}$ for $30 \mathrm{~min}$. before plating as indicated in the Results section.

Chemical estimations. Calcium was estimated by flame photometry on samples of bacterial pellets dry-ashed $\left(500^{\circ}, \mathrm{I} 6 \mathrm{hr}\right.$ ) and extracted with $0 \cdot \mathrm{I} \mathrm{N}-\mathrm{HCl}$. Dipicolinic acid in bacterial pellets was assayed by the method of Janssen, Lund \& Anderson (1958). For estimation of hexosamine, bacterial pellets were first hydrolysed $(6 \mathrm{~N}-\mathrm{HCl}, 5 \mathrm{hr}$, $\left.100^{\circ}\right)$ in sealed evacuated ampoules. Hexosamine was then determined by the Boas (1953) modification of the Elson and Morgan reaction using sodium carbonate blanks to lower non-specific colour due to sugars and amines, as suggested by Immers \& Vasseur (1950); glucosamine hydrochloride was the standard (Hamilton \& Stubbs, 1967). 
Electron microscopy. Bacterial suspensions were centrifuged and the pellets resuspended, for fixation, in potassium permanganate $(2 \%, \mathrm{w} / \mathrm{v})$ at $22^{\circ}$ for $90 \mathrm{~min}$. (spores) or $60 \mathrm{~min}$. (germinated spores) (Mollenhauer, 1959). The 'fixed' pellets were washed at least six times by centrifugation prior to embedding in Epon 812, wetsectioned and stained with uranyl acetate $(\mathrm{I} \% \mathrm{w} / \mathrm{v})$ for $10 \mathrm{~min}$. and examined in a JEM 6S electron microscope.

\section{RESULTS}

\section{Lethal effect of hydrostatic pressure}

When suspensions of spores of different species were subjected to different pressures for a constant time at $20^{\circ}$ the pattern of survivors (Table I) showed that pressure had inactivated the spores, but the greatest inactivation was not caused by the highest pressure. Intermediate pressures, i.e. between about 1000 and $3000 \mathrm{~atm}$. (depending on the organism), were most lethal.

Table I. Inactivation of spores of different species by hydrostatic pressure

\begin{tabular}{|c|c|c|c|c|c|c|c|c|c|}
\hline \multirow[b]{2}{*}{ Organism } & \multicolumn{9}{|c|}{ Survivors $(\%) *$ following pressurization $\dagger$ at $20^{\circ}$ for I $\mathrm{hr}$ at (atm.) } \\
\hline & 1000 & I 500 & 2000 & 2500 & 3000 & 4000 & 5000 & 6000 & 8000 \\
\hline $\begin{array}{l}\text { Bacillus cereus } \\
\quad \text { NCTC } 8035\end{array}$ & 18 & $2 \cdot 8$ & $8 \cdot 0$ & II & $11 \cdot 5$ & 34 & 28 & n.t. + & I I \\
\hline B. cereus $\mathrm{PX}$ & 98 & 0.85 & 0.90 & $6 \cdot 4$ & $8 \cdot 5$ & $I I \cdot 3$ & II & $7 \cdot 8$ & $5 \cdot 7$ \\
\hline $\begin{array}{l}\text { B. subtilis var. } \\
\text { niger (syn. } \\
\text { globigii) }\end{array}$ & 100 & $10 \cdot 2$ & $9 \cdot 8$ & $2 \cdot 5$ & 22 & $3 \mathrm{I}$ & 74 & 84 & 92 \\
\hline B. polymyxa & 100 & I 8 & $\mathrm{I} \cdot 8$ & $5 \cdot 7$ & 34 & 56 & n.t. & 68 & 42 \\
\hline
\end{tabular}

* Survivors were enumerated by poured plate viable counts.

$\dagger$ Spores $\left(c .10^{8} / \mathrm{ml}\right.$.) were suspended in sodium phosphate buffer $(0 \cdot 1 \mathrm{M}, \mathrm{pH} 8 \cdot 0)$ during pressurization.

Not tested.

Table 2. Comparison of continuous and discontinuous application of pressure on viability of spores

Organism

Bacillus subtilis var. niger (syn. globigii)

B. cereus $\mathbf{P X}$

\section{Application of pressure $\dagger$}

Continuous Discontinuous

Continuous

Discontinuous
Survivors $(\%) *$ following pressurization

$\overbrace{\text { Unheated spores }} \overbrace{\text { Heated sporest. }}$

$$
3 \cdot 5
$$

$\mathrm{I} \cdot 6$

0.45
I. 6

$4 \cdot 6$

0.30 0.30

* Spores $\left(\right.$ c. $10^{8} / \mathrm{ml}$.) were suspended in sodium phosphate buffer $(\mathrm{O} \cdot \mathrm{I} \mathrm{M}, \mathrm{pH} 8 \cdot \mathrm{\circ})$. Survivors were enumerated by poured plate viable counts.

$\dagger$ Pressure $\left(2000 \mathrm{~atm} ., 20^{\circ}\right)$ was applied either continuously for $\mathrm{I} \mathrm{hr}$, or discontinuously as a series of twelve 5 min. exposures.

$\ddagger$ Spores were heated for $30 \mathrm{~min}$. at $70^{\circ}$ following pressurization.

Spores in suspensions subjected to pressure for $\mathrm{I} \mathrm{hr}$ (as in Table $\mathrm{I}$ ) were inactivated to about the same extent whether held under pressure continuously or discontinuously, i.e. compressed and decompressed twelve times, each treatment being for a period of 5 min. (Table 2). This, and other experiments, showed that the extent of the inactivation 
depended on the duration of pressure treatment and not on the compression or decompression steps.

Spore concentration did not affect the extent of the inactivation, e.g. the survivor levels of spores of Bacillus coagulans pressurized in sodium phosphate (0.I M, $\mathrm{pH} \mathrm{8.0)}$ at $2000 \mathrm{~atm} ., 45^{\circ}$ for $\mathrm{I} \mathrm{hr}$, then heated at $70^{\circ}$ for $\frac{1}{2} \mathrm{hr}$ were $0 . \mathrm{I} 3,0.23,0.2 \mathrm{I}, 0.23$ and 0.24 respectively for initial viable spore concentrations of $2.6 \times 10^{9}, 2.7 \times 10^{8}, 2.5 \times 10^{7}$, $2.5 \times 10^{6}$ and $2.6 \times \mathrm{IC}^{5}$ per $\mathrm{ml}$.

\section{Effect of temperature on the inactivation of spores by pressure}

Inactivation of spores by pressure was strongly influenced by temperature. Figure I $a$ summarizes the results of experiments with spores of Bacillus coagulans. Similar but less exhaustive experiments were performed with spores of $B$. cereus strains T, PX

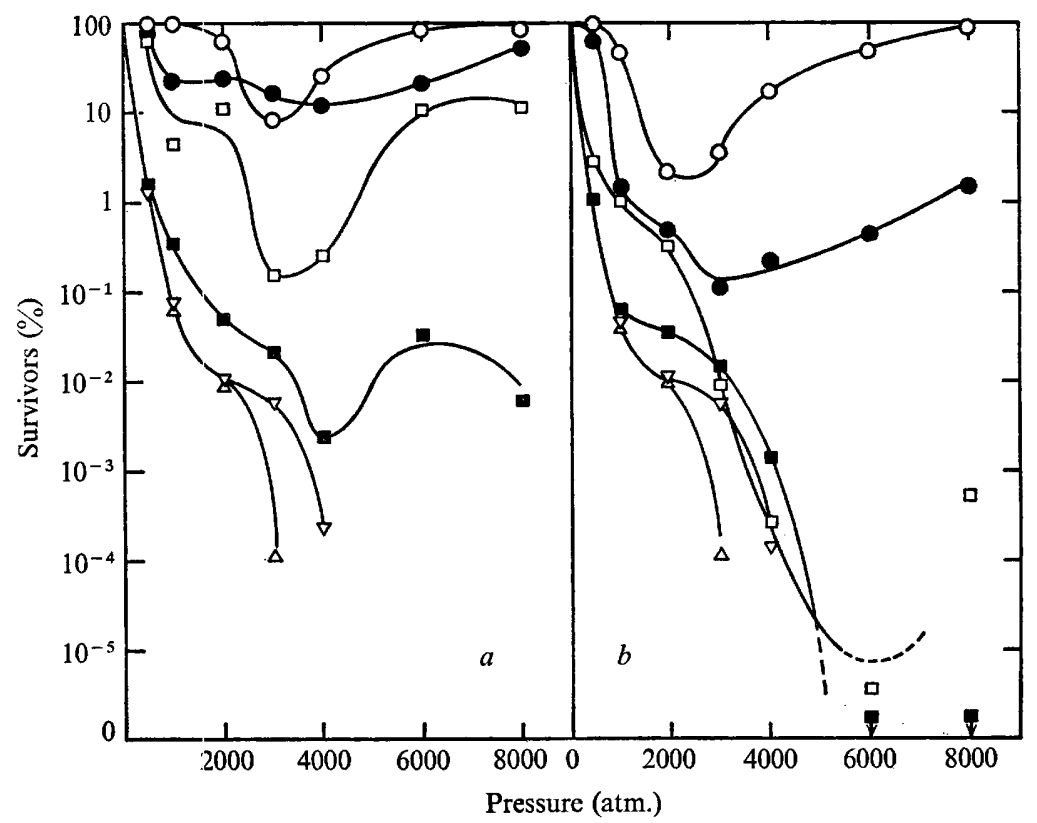

Fig. I. Inactivation of spores of Bacillus coagulans at different pressures and temperatures. (a) Spores $\left(c .10^{8} / \mathrm{mll}\right.$.) were heated at $70^{\circ}$ for $30 \mathrm{~min}$., then pressurized at the indicated temperatures and pressures for $30 \mathrm{~min}$. The suspending medium was sodium phosphate buffer (O. I M, pH 8.0). Survivors were enumerated by viable counts using poured plates. Temperatures of pressurization were: $25^{\circ}(\bigcirc) ; 35^{\circ}(\bullet) ; 45^{\circ}(\square) ; 55^{\circ}(\square) ; 65^{\circ}(\nabla) ; 75^{\circ}(\triangle)$. (b) As Fig. I $a$, but spore suspensions were additionally heated at $70^{\circ}$ for $30 \mathrm{~min}$. following pressurization in order to inactivate forms which had been heat-sensitized but not inactivated by pressure. (Arrows indicate that survivors were not detected and were therefore less than indicated by the symbol.)

and NCTC 8035 , B. subtilis var. niger (syn. globigii), B. polymyxa $\mathrm{M} \mathrm{I}$ and Clostridium sporogenes PA 3679 . The same qualitative pattern was seen with all these organisms. Four well-defined regions of response to pressure could be recognized (Fig. I $a$ ): (I) a region of increased inactivation with increased pressure up to about I000 atm.; (2) a tendency to plateau around 2000 to $3000 \mathrm{~atm}$; (3) a region of further increased 
inactivation; (4) a region above about $4000 \mathrm{~atm}$. where the inactivation decreased at temperatures below $55^{\circ}$ but increased at higher temperatures.

When samples of spores from the experiment reported in Fig. I $a$ were heated at $70^{\circ}$ for $30 \mathrm{~min}$. following pressurization below $65^{\circ}$, the inactivation was increased (Fig. $1 \mathrm{~b}$ ); the increase was particularly evident in the lower temperature and pressure regions (compare Fig. I $a, b$ ). Since the temperature of $70^{\circ}$ (for $30 \mathrm{~min}$.) was well below that which inactivates untreated spores, pressure, in addition to inactivating spores, increased the sensitivity of a proportion of the survivors to heat.

The storage temperature following pressure treatment was unimportant, except as indicated in Fig. I $a, b$. For instance, the survivor levels of spores of Bacillus coagulans following pressurization at $1000 \mathrm{~atm}$. (at $70^{\circ}$ for $30 \mathrm{~min}$.) and incubation for $\mathrm{I} \mathrm{hr}$ at $0,25,37,45,55$ and $65^{\circ}$ were respectively $\mathrm{I} \cdot 2, \mathrm{I} \cdot 2, \mathrm{I} \cdot \mathrm{I}, \mathrm{I} \cdot \mathrm{I}, \mathrm{I} \cdot \mathrm{I}$ and $0.9 \%$.

\section{Kinetics of inactivation of spores by pressure}

Figure 2 shows the rates of inactivation of spores of three species by pressure at $70^{\circ}$. No single response was apparent: semilog inactivation curves were typically concave, but with an initial rapid drop in numbers of survivors for Bacillus coagulans at the

(a)

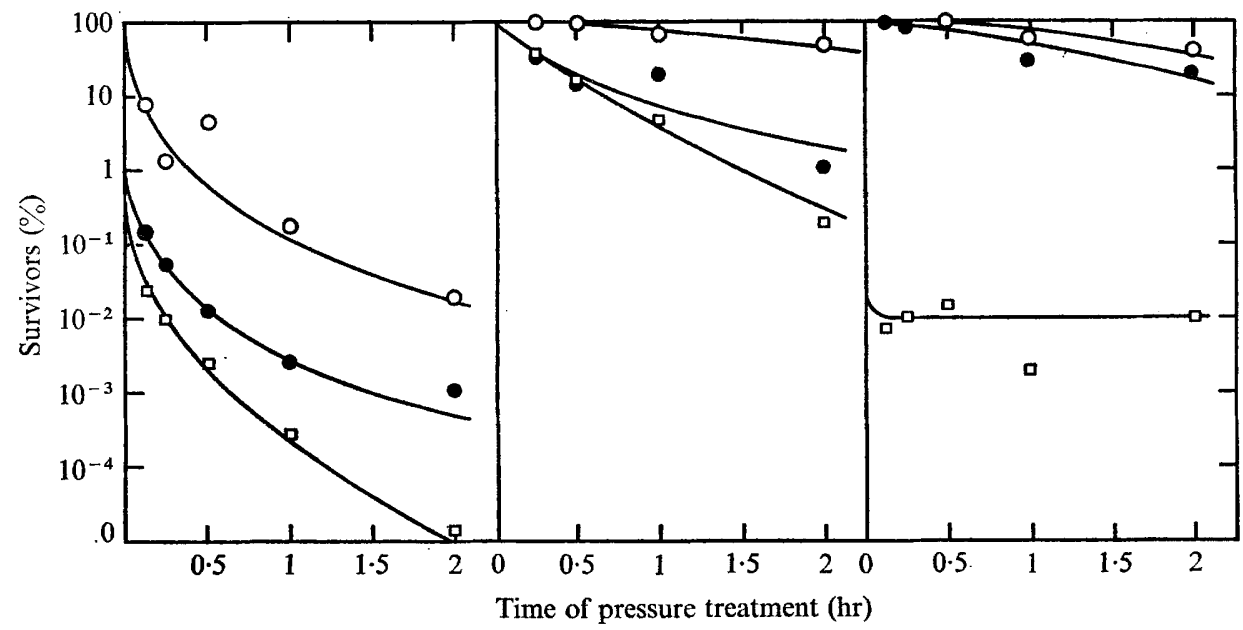

Fig. 2. Kinetics of inactivation of spores by pressure. Spores $\left(\right.$ c. $10^{8} / \mathrm{ml}$. $)$ were heated at $70^{\circ}$ for $30 \mathrm{~min}$., then pressurized at $70^{\circ}$. The suspending medium was sodium phosphate buffer $(\mathrm{O} \cdot \mathrm{I} \mathrm{M}, \mathrm{pH} 8 \cdot \mathrm{\circ})$. Survivors were enumerated by viable counts using poured plates. Organisms were: (a) Bacillus coagulans; (b) Bacillus subtilis A; (c) Clostridium sporogenes. Pressures

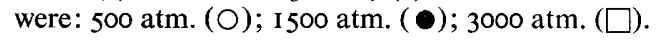

higher pressures (Fig. $2 a$ ); the rate of inactivation of the more pressure-resistant spores of $B$. subtilis A was slow but approximately exponential (Fig. $2 b$ ); spores of Clostridium sporogenes held at 3000 atm. were about $99.99 \%$ inactivated within a few minutes, but the surviving $0.01 \%$ of the population resisted further inactivation for at least $2 \mathrm{hr}$ (Fig. 2c).

\section{Appearance of spores}

The optical density of spore suspension fell when the spores were inactivated, or merely sensitized to heat by pressure. On examination by phase-contrast microscopy, 
spores which had been inactivated or sensitized to heat by pressure always had changed from bright to dark, as happens when spores germinate. Examination with the electron microscope revealed structural changes which were typical of the changes seen in germinating spores (Plate I).

\section{Chemical changes}

The chemical changes that occur on germination were sought and found to occur when spores were subjected to pressure. Pressure caused spores to excrete calcium, dipicolinic acid and hexosamine-containing material (Table 3).

Table 3. Phase-darkening and release of dipicolinic acid, calcium and hexosamine from spores during pressurization

\begin{tabular}{|c|c|c|c|c|c|c|}
\hline \multirow[b]{2}{*}{ Organism } & \multirow[b]{2}{*}{$\begin{array}{l}\text { Pressure* } \\
\text { (atm.) }\end{array}$} & \multirow[b]{2}{*}{$\begin{array}{l}\text { Time } \\
(\mathrm{hr})\end{array}$} & \multicolumn{3}{|c|}{ Constituent released $(\%)$} & \multirow[b]{2}{*}{$\begin{array}{l}\text { Phase-dark } \\
\text { spores }(\%)\end{array}$} \\
\hline & & & $\begin{array}{l}\text { Dipicolinic } \\
\text { acid }\end{array}$ & Calcium & Hexosamine & \\
\hline Bacillus cereux $\mathrm{PX}$ & 2000 & I & $9 \mathrm{I} \cdot 7$ & 92 & - & -- \\
\hline B. polymyхa м I & 2000 & I & 86 & $69 \cdot 5$ & 48 & - \\
\hline \multirow[t]{2}{*}{$\begin{array}{l}\text { B. subtilis var. niger } \\
\text { (syn. globigii) }\end{array}$} & 1000 & $\begin{array}{l}\frac{1}{2} \\
\text { I } \\
2\end{array}$ & $\begin{array}{l}72 \cdot 8 \\
74 \cdot 2 \\
85\end{array}$ & - & $=$ & $\begin{array}{l}81 \\
83 \\
88\end{array}$ \\
\hline & 6000 & $\begin{array}{l}\frac{1}{2} \\
1 \\
2\end{array}$ & $\begin{array}{l}87 \cdot 3 \\
98 \cdot 2 \\
9 I \cdot 7\end{array}$ & $\begin{array}{l}- \\
- \\
-\end{array}$ & $\underline{-}$ & $\begin{array}{l}97 \\
97 \\
96\end{array}$ \\
\hline
\end{tabular}

* Temperature during pressurization was $20^{\circ}$. Spores $\left(\right.$ c. $10^{8} / \mathrm{ml}$.) were suspended in water.

\section{Effect of heat and of $\gamma$-radiation prior to pressurization}

When spores of some species were sublethally heated prior to pressurization, their sensitivity to pressure at the lower temperatures and pressures increased. However, spores pressurized at higher temperatures (e.g. $65^{\circ}$ ) could be rendered more resistant to pressure by prior heating above about $70^{\circ}$ (Fig. 3). (The low survivor level at $90^{\circ}$ in Fig. 3 was due to inactivation by the high temperature alone.)

Exposure to $\gamma$-radiation sufficient to inactivate a proportion of the spores in a suspension caused an increase in the pressure sensitivity of the survivors (Table 4 ).

\section{Inacitivation of spores by pressure at different $\mathrm{pH}$ values}

Figure 4 shows the effect on survivor levels of pressurizing spores in various buffers at different $\mathrm{pH}$ values. (Although pressure will change the $\mathrm{pH}$ value of buffer solutions, the changes in these experiments were estimated not to exceed about $0.4 \mathrm{pH}$ units; Distèche, 1959.) The nature of the buffer seemed unimportant, and spores were inactivated by pressure over a wide $\mathrm{pH}$ range. However, the inactivation was greatest near neutrality and was definitely lowered at extreme $\mathrm{pH}$ values.

\section{Decrease in pressure inactivation of spores by ions}

Spores were pressurized in various solution of known water activity $\left(\mathrm{a}_{\mathrm{w}}\right)$. Figure 5 summarizes four experiments which suggested that non-ionic solutes (sucrose, glycerol) at low $a_{w}$ had little effect on the inactivation of spores by pressure, whereas ionic 
solutes $\left(\mathrm{NaCl}\right.$ and, more effectively, $\mathrm{CaCl}_{2}$ ) decreased the inactivation. The spores were therefore more likely protected from the inactivating effects of pressure by high concentrations of ions rather than by low $a_{w}$ per se. Below $a_{w}$ about 0.96 , additional salt had proportionally less effect than above $\mathrm{a}_{\mathrm{w}} 0.96$.

\section{Spores of different species}

When suspensions of spores of different species were subjected to pressure, the same phenomena were observed as recorded above, i.e. some spores were inactivated

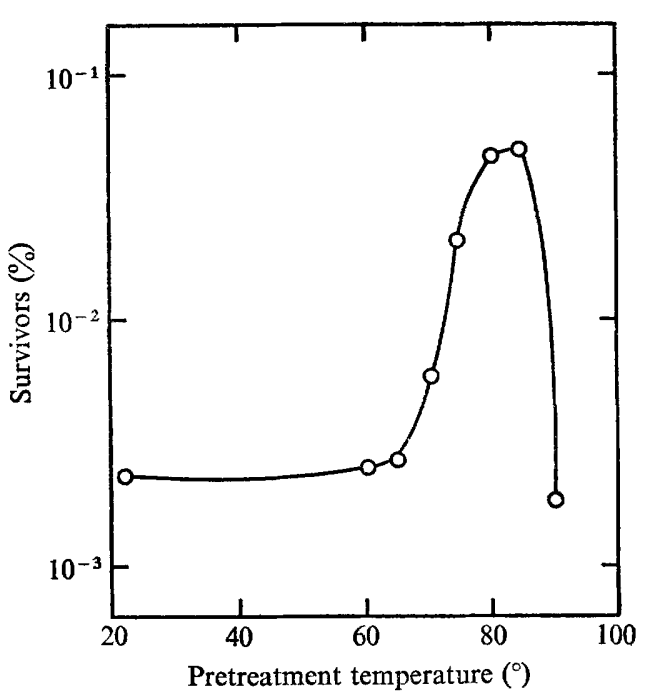

Fig. 3

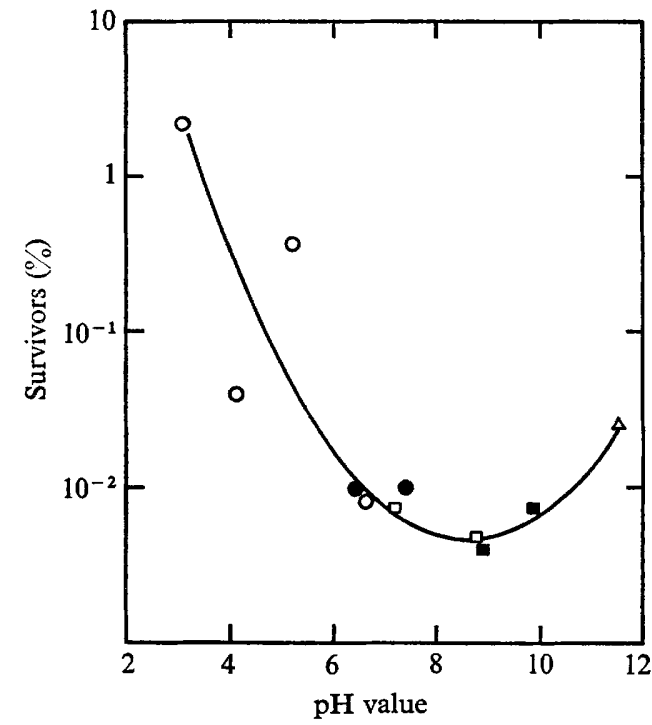

Fig. 4

Fig. 3. Decreased pressure-sensitivity of preheated spores of Bacillus coagulans. Spores (c. $10^{8} / \mathrm{ml}$. in sodium phosphate buffer; $0.1 \mathrm{M}, \mathrm{pH} 8.0$ ) were heated for $30 \mathrm{~min}$. at the temperatures indicated prior to pressurization at $1000 \mathrm{~atm}$. for $30 \mathrm{~min}$. at $65^{\circ}$.

Fig. 4. Inactivation of spores of Bacillus coagulans by pressure at different $\mathrm{pH}$ values. Spores (c. $10^{8} / \mathrm{ml}$.) were heated at $70^{\circ}$ for $30 \mathrm{~min}$., then pressurized at $1000 \mathrm{~atm}$. for $30 \mathrm{~min}$. at $65^{\circ}$. The symbols refer to different buffers (O.I M) as follows: sodium citrate/phosphate (O); sodium phosphate $(\bullet)$; tris (hydroxymethyl) aminomethane $/ \mathrm{HCl}(\square)$; sodium bicarbonate/ carbonate $(\mathbf{\square})$; sodium carbonate/hydroxide $(\triangle)$.

\section{Table 4. Increased pressure sensitivity of $\gamma$-irradiated spores of Bacillus coagulans}

Survivors $(\%)^{*}$ following pressurization of spores surviving $\gamma$-irradiation $\dagger$

$$
\begin{aligned}
& \text { Pressure and } \\
& \text { temperature } \\
& \text { I } 500 \text { Atm., } 45^{\circ} \\
& \text { I000 Atm., } 65^{\circ}
\end{aligned}
$$

$\begin{array}{ccc}\begin{array}{c}\text { Control (no } \\ \text { irradiation) }\end{array} & 0.2 \mathrm{Mrad} & 0.5 \mathrm{Mrad} \\ 5.5 \times 10^{-2} & 8.0 \times 10^{-3} & 3.1 \times 10^{-4} \\ \mathrm{I} \cdot 9 \times \mathrm{IO}^{-2} & 3.5 \times \mathrm{IO}^{-3} & \mathrm{I} \cdot 0 \times \mathrm{IO}^{-4}\end{array}$

* Survivors were enumerated by poured plate viable counts. Radiation alone inactivated spores to the following extent: $0.2 \mathrm{Mrad}, 20 \%$ survivors; $0.5 \mathrm{Mrad}, 2 \cdot 2 \%$ survivors.

$\dagger$ Spores $\left(c .1 \mathrm{r}^{8} / \mathrm{ml}\right.$.) were irradiated and pressurized in sodium phosphate buffer (0.1 M, pH 8.0), and were heated at $70^{\circ}$ for $30 \mathrm{~min}$. prior to counting. 
and some became heat-sensitive in the manner shown in Fig. I $a, b$, and individual spores became phase-dark as if germinated. However, the extent of inactivation varied greatly with different organisms (Table 5 ). Those spores which are most easily germinated by 'physiological' germinants at I atm. (e.g. Bacillus polymyxa, B. cereus) were in general more pressure-sensitive than those spores which are most dormant at I atm. (e.g. B. subtilis A, and mixed spores from soil; Table 5). 'Superdormant' spores of $B$. polymyxa and $B$. cereus (i.e. those spores in a population which remained ungerminated in a medium which caused germination of the majority) were likewise more resistant than the less dormant ones to the lethal effect of pressure (Table 5).

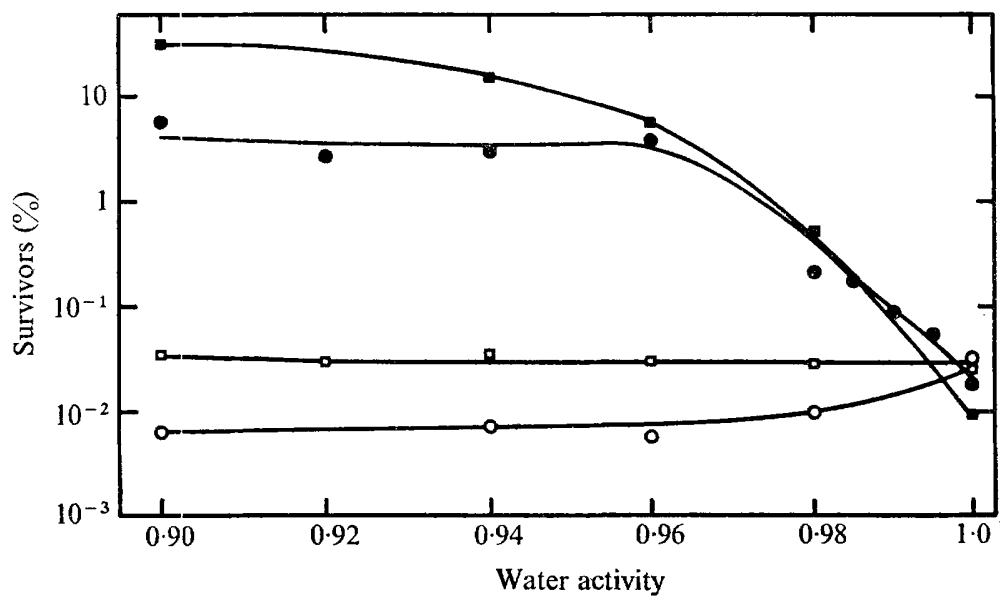

Fig. 5. Effect of ionic and non-ionic solutes on inactivation of Bacillus coagulans spores by pressure. Spores $\left(c .10^{8} / \mathrm{ml}\right.$.) were heated at $70^{\circ}$ for $30 \mathrm{~min}$., then resuspended in media of differing water activity $\left(\mathrm{a}_{\mathrm{w}}\right)$ and pressurized at $1000 \mathrm{~atm}$. for $30 \mathrm{~min}$. at $65^{\circ}$. Compounds used to adjust $\mathrm{a}_{\mathrm{w}}$ were: sucrose $(O)$; glycerol $(\square)$; sodium chloride ( $\bullet$ ); calcium chloride (D). In addition, the suspensions contained buffer $(0 . \mathrm{I} \mathrm{M}, \mathrm{pH} 8.0$; not taken into account in $\mathrm{a}_{\mathrm{w}}$ estimation) which was tris (hydroxymethyl) amino methane/ $\mathrm{HCl}$ when calcium chloride was present, or otherwise sodium phosphate.

Table 5. Inactivation of 'superdormant' spores by pressure

\begin{tabular}{|c|c|c|c|c|}
\hline & \multicolumn{4}{|c|}{ Survivors $(\%) *$ following pressurization $\dagger$ for $\mathrm{I} \mathrm{hr}$ at } \\
\hline rganism & $\begin{array}{c}2000 \mathrm{~atm} . \\
20^{\circ}\end{array}$ & $\begin{array}{c}2000 \mathrm{~atm} \\
50^{\circ}\end{array}$ & $\begin{array}{c}2000 \text { atm } \\
70^{\circ}\end{array}$ & $\begin{array}{c}3000 \mathrm{~atm} \\
70^{\circ}\end{array}$ \\
\hline cereus $\mathbf{P X}$ & 0.037 & 一 & - & - \\
\hline $\begin{array}{l}\text { us PX 'super- } \\
\text { hant' fraction }\end{array}$ & 0.75 & - & - & - \\
\hline$n y x a$ M $\mathrm{I}$ & 0.094 & 一 & - & - \\
\hline $\begin{array}{l}\text { myха м I } \\
\text { erdormant' fraction }\end{array}$ & 15 & - & - & - \\
\hline is NCTC 8035 & 0.08 & - & - & - \\
\hline $\begin{array}{l}\text { bilis var. niger (syn. } \\
\text { bigii) }\end{array}$ & $I \cdot 7$ & 0.09 & 0.0015 & 0.0003 \\
\hline lans NCTC 399I & I I 5 & $0 \cdot I$ & 0.0075 & 0.0037 \\
\hline oil spores & - & - & 0.28 & 0.23 \\
\hline & 100 & 64 & $3 \cdot 3$ & $4 \cdot 6$ \\
\hline
\end{tabular}

* Survivors were enumerated by poured plate viable counts.

$\dagger$ Spores were suspended in sodium phosphate buffer $(0 \cdot 1 \mathrm{M}, \mathrm{pH} 8 \cdot 0)$ during pressurization. 


\section{DISCUSSION}

The lethality of hydrostatic pressures in excess of about 1000 atm. for vegetative forms of bacteria is well documented. The most effective pressure depends on the organism, its habitat (e.g. terrestrial, or marine barophile) and stage of growth (see Introduction, and Zobell \& Johnson, 1949). Inactivation of vegetative bacteria, by pressure, also depended upon environmental factors; for instance, being most rapid at extreme $\mathrm{pH}$ values and lowered by the addition of protective substances such as salts or sugars (Timson \& Short, 1965).

The mechanism of inactivation of vegetative bacteria by pressure was suggested by Heden (1964) and Rutberg (1964) to involve damage to the processes of DNA replication, transcription or translation (Landau, 1967). Timson \& Short (1965) reasoned that damage may arise via electrostriction and the increase in ionization of weak electrolytes and proteins which is known to result from increase in pressure. Indeed, many studies with pure proteins have shown that high hydrostatic pressures initiate conformational changes which may result in denaturation(Johnson, Eyring \& Pollissar, 1954; Kalckar, 1962). Thus the increase in inactivation of vegetative bacteria that occurs with increase in pressure may result from denaturation of proteins.

In contrast to vegetative bacteria, spores resisted pressures well above those which cause the denaturation of free proteins. Furthermore, the pattern of inactivation of spores has been found in this study to differ from that of vegetative forms in a number of fundamental ways. For instance, inactivation of spores by pressure was most rapid near neutral $\mathrm{pH}$ values rather than in acid or alkali. In some instances, the denaturation of proteins by pressure, when it involves a decrease in protein molecular volume, can be counteracted by increasing the temperature, which generally causes an increase in protein molecular volume (Eyring, Johnson \& Gensler, 1946; Johnson et al. 1954). For example, Morita \& Haight (1962) reported that malic dehydrogenase was active at $\mathrm{IOI}^{\circ}$ under $\mathrm{I} 300 \mathrm{~atm}$. pressure. Analogous protection by pressure of vegetative bacteria (Johnson \& Lewin, I946) and spores (Johnson \& Zobell, I949) from inactivation by heat, and vice versa, has been reported. Results in the present paper, however, show that the temperature coefficient for inactivation of spores by pressure is very high, and that, far from counteracting the effect of pressure, heat that was insufficient alone to inactivate spores increased the inactivation caused by pressure.

The discovery of optimal values of $\mathrm{pH}$, temperature and pressure for inactivation of spores by pressure argues against the inactivation having resulted mainly from effects on nuclear material, translation, denaturation of proteins or increased solvation (like the lethal mechanism postulated for vegetative forms by Heden, I964; Timson \& Short, 1965; and Landau, 1967, or for spores by Clouston \& Wills, 1969). These mechanisms should generally cause progressively more inactivation as the pressure is raised. The possibility that hydrostatic pressure physically distorted spores sufficiently to cause inactivation was also unlikely since again one would expect high pressures always to cause greater inactivation than low pressures, and one would not expect the high temperature coefficient that was observed. Furthermore, hydrostatic pressure is not vectorial and therefore would not cause distortion of the sort that can disrupt and inactivate spores; i.e. squeezing under a microscope slide cover glass (Lewis, Snell \& Burr, 1960), shaking with glass beads (Curran \& Evans, 1942) or scraping with a wire loop (Knaysi \& Curran, I96I). The regions of pressure and temperature 
investigated were such that transitions through different ice phases under pressure (Bridgman, I937), which can disrupt vegetative bacteria (Edebo \& Heden, 1960), did not occur.

The observations that pressure caused heat sensitization of spores, initiated leakage of calcium, dipicolinic acid and hexosamine-containing material, and resulted in fall in optical density of suspensions and phase-darkening of individual spores, together with the electron-microscopical evidence, showed that pressure initiated changes in spore structure and function identical to those observed on germination (Hamilton \& Stubbs, 1967). Further evidence is provided by the pressure inactivation being greatest near neutral $\mathrm{pH}$ values. The effects of heat (Curran \& Evans, 1945) and $\gamma$-radiation (Gould \& Ordal, 1968) as 'activating' treatments for germination could explain their potentiation of the lethality of pressure for spores. Germination (at I atm.) is inhibited by ionic and non-ionic solutes in a similar manner to the inhibition of pressure inactivation of spores (Fig. 5). Spores which are most difficult to germinate completely with 'physiological' germinants at I atm. (e.g. soil spores; 'superdormant' spores, Table 5; Gould et al. 1968) were also the most resistant to inactivation by pressure. Taken altogether, the evidence leads to the conclusion drawn by Clouston \& Wills (1969) that pressure initiates germination (Gould \& Sale, 1970).

Presumably the shapes of the inactivation-pressure curves reflect the sensitivity to pressure of the gerrnination as well as the sensitivity of the germinated spores to pressure inactivation. At lower temperatures the lowest pressures caused germination and heat sensitization but were insufficient to cause appreciable inactivation of the resulting germinated forms. Medium pressures caused considerable germination and were high enough to inactivate a large proportion of the resulting germinated population. The overall effect was therefore to inactivate many but not all of the spores. The highest pressures caused less germination and again only a proportion of the germinated spore population was inactivated, so the overall effect was that the highest pressures caused less inactivation than medium pressures. At higher temperatures the germination was increased and most of the germinated spores were inactivated; always more spores were germinated and became heat-sensitive than were inactivated. Above $65^{\circ}$ the germination and inactivation curves coincided, suggesting that the pressuregerminated spores were directly inactivated by heat.

Although pressure induces germination, evidently not all the germinated spores are inactivated by pressure. It is also evident that at near room temperature, spores, whether germinated or not, have a remarkable resistance to extreme pressure.

We are indebted to Dr T. A. Roberts for radiation facilities, to Mr J. M. Stubbs for the electron micrographs and to Miss C. V. Martindale, Mr G. W. Gates and $\mathrm{Mr}$ A. K. Jackson for valuable technical assistance.

\section{REFERENCES}

BASSET, J. \& MACheboetuf, M. A. (1932). Étude sur les effets biologiques des ultrapressions: résistance des bactéries, des diastases et des toxines aux pressions tres élevées. Comptes Rendu Hebdomadaire des Séances de l'Académie des Sciences 196, I43I.

BoAs, N. F. (1953). Method for the determination of hexosamine in tissues. Journal of Biological Chemistry 204, 553 .

Brmgman, P. W. (I937). The phase diagram of water to $45,000 \mathrm{~kg} . / \mathrm{cm} .{ }^{2}$. Chemical Physics $\mathbf{5}, 964$.

Clouston, J. G. \& Wills, P. A. (1969). Initiation of germination and inactivation of Bacillus pumilis spores by hydrostaric pressure. Journal of Bacteriology $\mathbf{9 7}, 684$. 
Curran, H. R. \& Evans, F. R. (1942). The killing of bacterial spores in fluids by agitation with small inert particles. Journal of Bacteriology 43, 125.

Curran, H. R. \& Evans, F. R. (I945). Heat activation inducing germination in the spores of thermotolerant and thermophilic aerobic bacteria. Journal of Bacteriology 49, 335.

DisTècHe, A. (I959). pH measurements with a glass electrode withstanding $1500 \mathrm{~kg} . / \mathrm{cm} .{ }^{2}$ hydrostatic pressure. Review of Scientific Instruments 30, 474.

Edebo, L. \& Heden, C.-G. (1960). Disruption of frozen bacteria as a consequence of changes in the crystal structure of ice. Journal of Biochemical and Microbiological Technology and Engineering 2, II 3 .

Edwards, J. C., Busta, F. F. \& SpeCK, M. L. (1965). Thermal inactivation characteristics of Bacillus subtilis spores at ultra high temperatures. Applied Microbiology 13, 851.

Eyring, H., Johnson, F. H. \& Gensler, R. L. (1946). Pressure and reactivity of proteins, with special reference to invertase. Journal of Physical Chemistry, Ithaca, N.Y. 50, 453.

GibBs, B. M. \& Hirsch, A. (1956). Spore formation by Clostridium species in an artificial medium. Journal of Applied Bacteriology 19, I 29.

Gould, G. W., Jones, A. \& Wrighton, C. (1968). Limitations of the initiation of germination of bacterial spores as a spore control procedure. Journal of Applied Bacteriology 31, 357.

Gould, G. W. \& ORdal, Z. J. (I968). Activation of spores of Bacillus cereus by $\gamma$-radiation. Journal of General Microbiology 50, 77.

Gould, G. W. \& SALE, A. J. H. (I970). Initiation of germination of bacterial spores by hydrostatic pressure. Journal of General Microbiology 6o, 335.

Hamilton, W. A. \& Stubss, J. M. (1967). Comparison of the germination and outgrowth of spores of Bacillus cereus and Bacillus polymyxa. Journal of General Microbiology 47, 121.

HEDEN, C.-G. (1964). Effects of hydrostatic pressure on microbial systems. Bacteriological Reviews 28, 14 .

Hite, B. H. (I899). The effect of pressure in the preservation of milk. Bulletin of the West Virginia University Agricultural Experiment Station no. 58.

Hite, B. H., Giddings, N. J. \& Weakley, C. W. (I9I4). The effect of pressure on certain microorganisms encountered in the preservation of fruits and vegetables. Bulletin of the West Virginia University Agricultural Experiment Station no. 146.

IMMERS, J. \& VASSEUR, E. (I950). Influence of sugars and amines on the colorimetric hexosamine method of Elson and Morgan and its possible elimination. Nature, London 265, 898.

Janssen, F. W., Lund, A. J. \& Anderson, L. E. (1958). Colorimetric assay for dipicolinic acid in bacterial spores. Science, New York 127, 26.

Johnson, F. H. \& LewIN, I. (1946). The disinfection of Escherichia coli in relation to temperature, hydrostatic pressure, and quinine. Journal of Cellular Comparative Physiology 28, 23.

Johnson, F. H. \& ZoBell, C. E. (I949). The retardation of thermal disinfection of Bacillus subtilis spores by hydrostatic pressure. Journal of Bacteriology 57, 353 .

Johnson, F. H., Eyring, H. \& Polissar, M. J. (1954). The Kinetic Basis of Molecular Biology. New York: John Wiley and Sons, Inc.

KALCKAR, H. M. (1962). Some properties of antispace research in biology. In Horizons in Biochemistry. Ed. by M. Kasha and B. Pullman, p. 5I3. London: Academic Press.

KnAysi, G. \& Curran, F. R. (I96I). Effects of some mechanical factors on the endospores of Bacillus subtilis. Journal of Bacteriology 82, $69 \mathrm{I}$.

LANDAU, J. V. (I967). Induction, transcription and translation in Escherichia coli: a hydrostatic pressure study. Biochimica et Biophysica Acta 149, 506.

Larson, W. P., Hartzell, T. B. \& Diehl, H. S. (19I8). The effect of high pressures on bacteria. Journal of Infectious Diseases 22, 27I.

Lewis, J. C., SNell, N. S. \& Burr, H. K. (1960). Water permeability of bacterial spores and the concept of a contractile contex. Science, New York 132, 544.

MANning, W. R. D. (1963). High pressure engineering. Bulleid Memorial Lectures. Vol. I. University of Nottingham.

Mollenhauer, H. M. (1959). Permanganate fixation of plant cells. Journal of Biophysical and Biochemical Cytology 6, 431 .

Morita, R. Y. \& Haight, R. D. (I962). Malic dehydrogenase activity at $10 I^{\circ} \mathrm{C}$ under hydrostatic pressure. Journal of Bacteriology 83, $134 \mathrm{I}$. 
RoberTs, T. A. \& Hitchins, A. D. (I969). Resistance of spores. In The Bacterial Spore. Ed. by G. W. Gould and A. Hurst, p. 6r1. London: Academic Press.

RUTBERG, L. (1964). On the effects of high hydrostatic pressure on bacteria and bacteriophage. Acta Pathologica et Microbiologica Scandinavica 6r, 8I, 9I and 98.

Timson, W. J. \& SHORT, A. J. (I965). Resistance of micro-organisms to hydrostatic pressure. Biotechnology and Bioengineering 7, $\mathrm{I} 39$.

ZOBell, C. E. \& JoHNSON, F. H. (1949). The influence of hydrostatic pressure on the growth and viability of terrestrial and marine bacteria. Journal of Bacteriology 57, 179.

\section{EXPLANATION OF PLATE}

Plate I. Micrographs of thin sections of spores fixed with potassium permanganate. The scale mark represents $1000 \AA$.

A. Ungerminated spore of Bacillus cereus $\mathrm{PX}$, showing wide cortex zone $(C X)$.

B. Spore of Bacillus cereus PX germinated by incubation at $37^{\circ}$ for $10 \mathrm{~min}$. in buffer (sodium phosphate, $0 . \mathrm{I} \mathrm{M}, \mathrm{pH} 8.0$ ) plus the germinants inosine (I $00 \mu \mathrm{M})$ and L-alanine (I mM).

C. Spore of Bacillus cereus PX germinated by pressurization at $2000 \mathrm{~atm} .\left(20^{\circ}, \mathrm{I} \mathrm{hr}\right)$ in nutrient-free buffer (sodium phosphate, $0 \cdot 1 \mathrm{M}, \mathrm{pH} 8 \cdot 0$ ). 
Journal of General Microbiolog.', Vol. 60, No. 3

Plate I
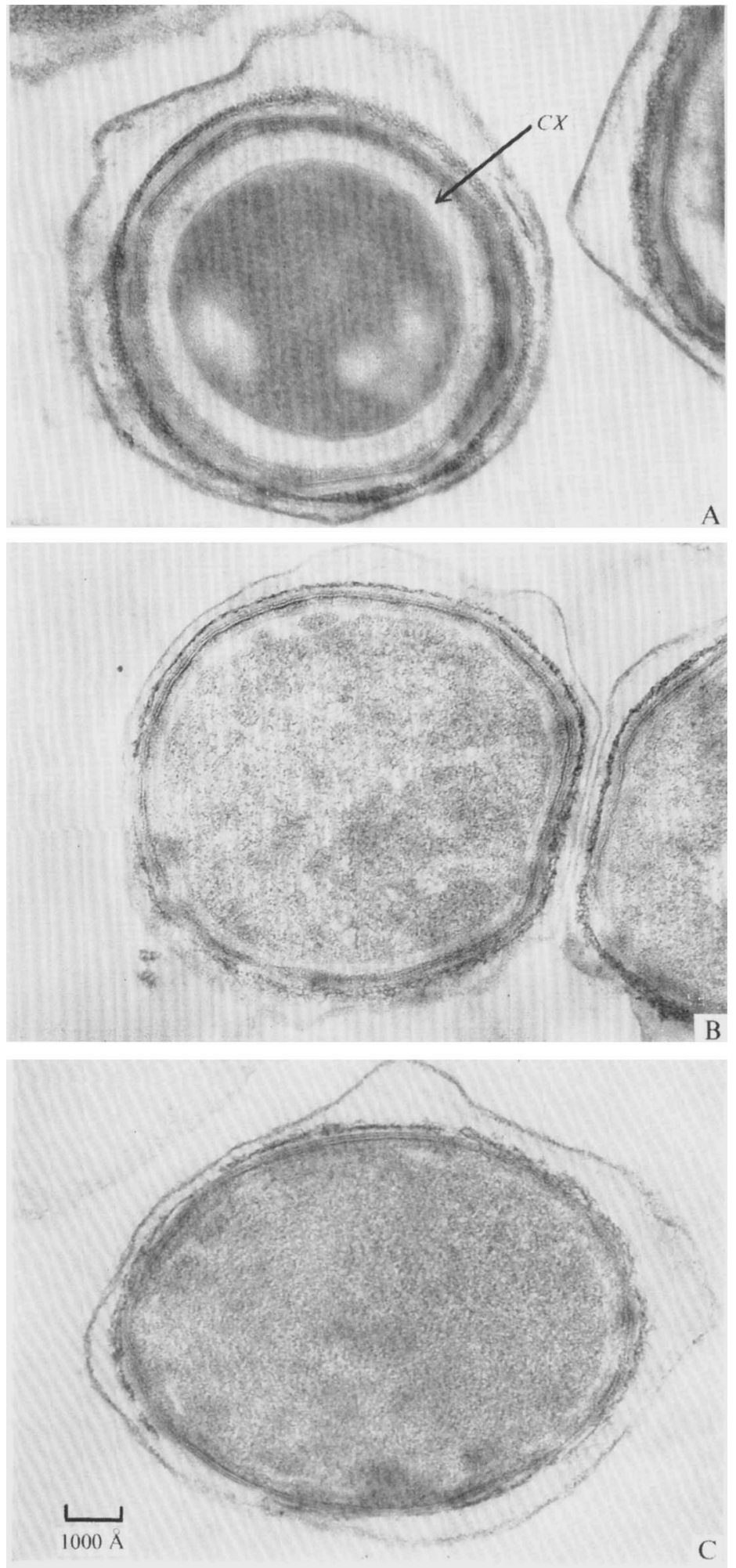